Open Access

\title{
Innovation at country-level: association between economic development and patents
}

Viju Raghupathi ${ }^{{ }^{*}}$ and Wullianallur Raghupathi ${ }^{2}$

\author{
* Correspondence: \\ VRaghupathi@brooklyn.cuny.edu \\ ${ }^{1}$ Koppelman School of Business, \\ Brooklyn College of the City \\ University of New York, 2900 Bedford \\ Ave, Brooklyn, NY 11210, USA \\ Full list of author information is \\ available at the end of the article
}

\begin{abstract}
This study analyzes the role of economic indicators in country-level innovation, represented by patents in the technology sector. Innovation indicators include the ratio of patents owned by foreign residents and the number of patent applications in each industry in the technology sector. Economic indicators include GDP, gross national income, labor cost, R\&D expenditure, real minimum wage, tax revenue, and education enrollment. The data for OECD countries collected from stats.oecd. org for 2000 to 2010 is analyzed using Cognos. Results show that countries with low GDP rely on foreign collaboration for innovation; education enrollment stimulates innovation; among the sectors, government and higher education have higher R\&D expenditures than private and non-profit sectors. A significant contribution of our research lies in the dimension of internationalization and ownership of technology innovation. We suggest viable solutions for countries facing tax revenue losses arising from mobility of patents.
\end{abstract}

Keywords: Economic development, Patent, Industry, OECD, Education enrollment, Cognos, Business intelligence, Innovation

\section{Background}

Today, the world's societies face severe economic and social challenges. The economic downturn of 2008-2009 has led to reduced growth, rising unemployment, and soaring public debt. To recover, countries need to find new and sustainable sources of growth. Innovation-the introduction of a new or significantly improved product, process, or method-holds the key to boosting economic growth and productivity. Innovation has much broader implications than Research \& Development and is influenced by a wider range of factors. Innovation can help accelerate economic recovery and put countries on a path to sustainable and greener growth. Innovation allows a country to discover opportunities that exist or are likely to emerge in time, to focus on existing business processes and practices that improve efficiency, to find potential customers, to minimize wastage, and to increase profits.

Innovation is a key driver of technology development and economic growth. It provides a means of satisfying the demands of the current market and the potential needs of future markets. Innovation is achieved through more effective products, processes, services, or technologies that are readily available to the current market. There is an

(c) The Author(s). 2017 Open Access This article is distributed under the terms of the Creative Commons Attribution 4.0 International License (http://creativecommons.org/licenses/by/4.0/), which permits unrestricted use, distribution, and reproduction in any medium, provided you give appropriate credit to the original author(s) and the source, provide a link to the Creative Commons license, and indicate if changes were made. 
increased awareness and recognition among national policy makers about innovation as a key factor in economic growth. Many OECD (Organization for Economic Cooperation and Development)-member countries have enforced strategies and policies to enhance innovation and economic development.

Innovation has different implications for different economies such as developing, emerging, and developed. It is important that we develop tools to measure innovation across diverse economies. Various financial, industrial, economic, and social indicators are associated with trends in innovation.

Innovation is a crucial factor in national progress. The application of advanced technology along with entrepreneurship and innovation approaches in creation of goods and services results in translation of scientific and technological advances into productive economic activity. This contributes to economic growth when aided by environmental and regulatory structures. Policy makers look to regulatory framework as an instrument to promote innovation (Blind et al. 2004). The bridge between administrative or institutional regulations and innovation is through intellectual property rights (such as patents and copyrights). Policy makers can calibrate the strength of patent protection rights to have an influence on the country's innovation. As it stands now, research on innovation is fragmented. A general framework of analysis and greater coordination of research efforts will serve to offer a holistic view of the phenomenon, starting from its inputs to its economic and social impact. Innovation has become a multidimensional concept; it is not just about producing new products. It is also about services, technical standards, business models, and processes.

What are the key economic factors that determine the success of innovation at a country level? This study addresses the question by exploring the association between economic indicators and innovation (represented by patents) for OECD countries for the years 2000 to 2010. Though other studies have looked at economic growth and innovation, the uniqueness of our study lies in utilizing a large data set that spans a longitudinal period and in deploying a sophisticated analytic tool such as Cognos, in drilling down and identifying patterns and relationships in the data.

The remainder of this paper is organized as follows: Section "Research background" provides research background; Section "Methods" describes research methodology; Section "Results and discussion" contains the results and discussion of data analyses; Section "Scope and limitations" outlines the scope and limitations of the research; and Section "Conclusions" offers conclusions along with contributions and implications.

\section{Research background}

Innovation is an important element in the long-term growth and development of an economy. Over time, various definitions and characterizations of innovation have been offered, such as: innovation often arises from novel combinations of existing knowledge (Schumpeter 1934); centers on concepts of renewal, modernization, and change (King and Anderson 2002); and is something new and intended with an often uncertain, risky, and unpredictable outcome (Angle 2000). Innovation has been studied at the individual (Miron et al. 2004), the group 
(Huelsheger et al. 2009), and the organizational level (Smith et al. 2008). Education and learning are some key factors for innovation (Leonard and Sensiper 1998).

Innovation and economic growth are intricately associated. Each drives the other, thus, innovation is a key component in a government's political agenda (Hsu et al. 2014). Economic indicators have an impact on innovation at various levels: firm, state, and country. In this study, we focus on country-level innovation-specifically, technological innovation represented by patents.

Over the last few years, there has been innovation in various industries, particularly in the technology sector. An important indicator of technological innovation is intellectual property (IP), an umbrella term for patents, copyrights, and other creative expressions. Studies have explored the association between stronger patent rights, innovation, and economic growth. The relationship of patents to economic growth arises out of the rationale that stronger patent rights positively influences innovation through costsaving technologies and new product development, which in turn promote economic growth (Kanwar and Evenson 2003; Hudson and Minea 2013). Research in this arena has not always been consistent, however. Park and Ginarte (1997) used an index of patent rights compiled for 60 countries by Ginarte and Park (1997), to study the relationship between patent rights, economic growth, and R\&D expenditure. While they found a positive association between strong patent rights and R\&D expenditure for upper income OECD countries, they found no association for low- income countries. In addition, they found no relationship between patent rights and economic growth. On the other hand, Hudson and Minea (2013) found patent rights, along with GDP per capita, to positively influence economic growth. Park (2003) analyzed data for 18 manufacturing industries between the years 1980 and 1995 for 21 OECD countries and found a positive relationship of patents with labor productivity and R\&D expenditure. However, for a larger sample of countries, they found that while R\&D expenditure increased with patents, labor productivity did not. In an analysis of 32 countries between the years 1981 and 1990, Kanwar and Evenson (2003) found a positive relationship between patent rights and $R \& D$ intensity (ratio of $R \& D$ expenditure to GDP). Kim et al. (2008) found that patent rights for developed countries were associated with higher R\&D intensity. Research is therefore varied and brimming with inconsistent results, which points to the need for more analysis and discoveries.

Where innovation is concerned education plays an important role in the economy. Research at universities and public research institutions contributes to innovation through publications that result in the creation of codified knowledge for potential technological innovations by businesses. Countries are investing their resources in academic research, doctoral education, and the knowledge transfer from these institutions. For example, United States legislation such as the Bayh-Dole Act of 1980 has allowed universities to have ownership of intellectual property (IP), which in turn enabled universities to form alliances with the private sector, venture capital industry, and foreign firms. These alliances have resulted in over 42,000 licensing deals and the formation of more than 4500 companies (Atun et al. 2007), contributing to major revenue for the economy. While national legislative frameworks such as the Bayh-Dole Act authenticate the legitimacy of academic patenting activities, they also signal the development of local IP management practices such as IP rights and IP 
exploitation/incubation, with the objective of promoting economic growth (Weckowska et al. 2015). IP governance and regulation benefits economic growth by providing incentives for innovation without hindering transfer of knowledge (Atun et al. 2007). Note for example that countries with universities that support research commercialization show a higher rate of patents. Also, countries with a highly educated workforce can achieve higher economic wealth and available resources to invest in innovations (Rossberger and Krause 2015). It is therefore relevant to include education in the analysis of economic indicators of innovation in a country.

\section{Methods}

This study investigates the relationship between economic development and innovation at a country level for the OECD-member countries. Table 1 displays the research methodology.

The data source for the study is http://stats.oecd.org. Data on innovation and economic development for OECD-member countries was collected for the years 2000 to 2010. In this study, we use patents to represent innovation. This is appropriate since patents can be used to protect inventions by firms, institutions, or individuals (Granstrand 2005). The OECD's Directorate for Science, Technology and Industry maintains patent data by region and by technology. This study focuses on the patents by technology. Variables were selected at the country level for the longitudinal time period. Table 2 shows all the variables in the research.

The economic indicators include variables that cover financial, labor, research and development, and educational components of the economy. GDP per capita measures the total output of a country: it takes the gross domestic product and divides it by the population of the country. In studies involving country-level comparisons, this is very relevant because it reflects the relative performance. GNI per capita is the value of a country's total income in a year divided by its population, and indicates the average income per resident. Labor cost index is an important indicator that incorporates price changes as well as changes in the composition and characteristics of labor input. Since the direct and indirect costs of labor have the potential to vary by industry, it is important to consider the labor cost index as an indicator. Also, labor has an impact on the innovation level of an economy because it influences the production of goods or services. RED expenditure includes creative work undertaken systematically to increase the stock of knowledge and the use of knowledge to devise new applications, all of which have the potential to influence innovation. Real minimum wage is the statutory minimum wage converted into a common hourly and annual pay

Table 1 Research methodology

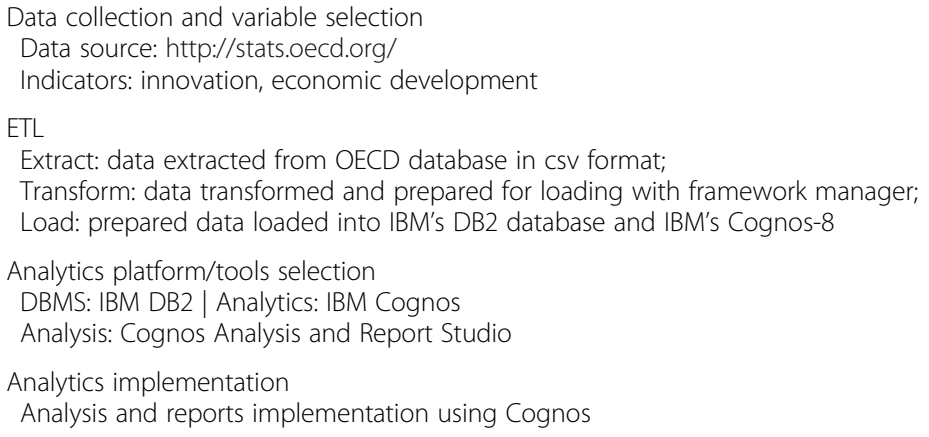


Table 2 Variables in the research

\begin{tabular}{|c|c|}
\hline Economic indicators & Description \\
\hline Gross domestic product (GDP) per capita (\$) & US \$ current PPP, current prices \\
\hline Gross national income (GNI) per capita (\$) & US \$ current PPP, current prices \\
\hline Labor cost index (base year 2010=100) & $\begin{array}{l}\text { Measures changes in average hourly labor cost, taking } \\
\text { into account not only price changes but also changes } \\
\text { in the composition and the characteristics of the labor } \\
\text { input; Calculated by dividing the labor costs by the } \\
\text { number of hours worked. Labor costs are made up of } \\
\text { costs for wages and salaries, plus non-wage costs such } \\
\text { as employer's social contributions. These do not include } \\
\text { vocational training costs or other expenditures such as } \\
\text { recruitment costs, and spending on working clothes. }\end{array}$ \\
\hline Research \& development (R\&D) expenditure (\$) & $\begin{array}{l}\text { Money spent on creative work undertaken on a } \\
\text { systematic basis to increase the stock of knowledge } \\
\text { and the use of this knowledge to devise new } \\
\text { applications in the sector }\end{array}$ \\
\hline Real minimum wage $(\$)$ & $\begin{array}{l}\text { Statutory minimum wages converted into a common } \\
\text { hourly and annual pay period (in US\$) for the OECD } \\
\text { countries for which they are available. }\end{array}$ \\
\hline Tax revenue as percentage of GDP (\%) & Tax Revenue expressed as a percentage of GDP \\
\hline $\begin{array}{l}\text { Ratio of education enrollment to total population } \\
\text { (enrollment in } 3 \text { levels of primary, secondary, tertiary) }\end{array}$ & $\begin{array}{l}\text { Ratio of enrollment in primary, secondary, and tertiary } \\
\text { education levels expressed with the total population }\end{array}$ \\
\hline Innovation indicators & Description \\
\hline $\begin{array}{l}\text { PCT (Patent cooperation treaty) patent applications } \\
\text { per 10,000 inhabitants }\end{array}$ & $\begin{array}{l}\text { Number of patent applications in PCT per 10,000 } \\
\text { inhabitants (reference date is application date) }\end{array}$ \\
\hline Patents owned by foreign residents & $\begin{array}{l}\text { Patents owned by foreign countries (drill down to } \\
8 \text { countries including EU) }\end{array}$ \\
\hline Patent applications under PCT by technology sector & $\begin{array}{l}\text { Number of patent applications by technology for } \\
\text { different sectors (sectors include chemistry/metallurgy; } \\
\text { electricity; human necessities; fixed construction; } \\
\text { mechanical engineering, lighting, heating; performing } \\
\text { operations/transportation; physics; textiles/paper) }\end{array}$ \\
\hline
\end{tabular}

period (in US\$) in the OECD countries for which they are available. Tax revenue as percentage of GDP represents the percentage of revenues collected from taxes on income and profits, social security contributions, goods and services, payroll, and all other taxes. It reflects the degree to which the government controls an economy's resources. Ratio of education enrollment to total population represents the enrollment in primary, secondary, and tertiary education expressed as a ratio to the total population. This is another important economic indicator, with the potential to influence innovation at a country level.

Our innovation indicators include the patent statistics extracted from the patents by technology category. The Patent Cooperation Treaty (PCT) offers a unified procedure for filing patent applications with the objective of protecting the intellectual property in each of its contracting members. PCT patent application per 10,000 inhabitants represents the number of applications per 10,000 inhabitants filed under the PCT. Patents owned by foreign residents represent patents that are given for inventors who are not residents of the country in which the application is made. For a variety of economic reasons, inventors can apply for patents in a country outside of their country of residence. Patent applications under PCT by technology sector includes the number of patent applications for different sectors such as chemistry/metallurgy, electricity, human necessities, fixed construction, mechanical engineering/lighting/heating, performing operations/transportation, physics, and textiles/paper. 
IBM Cognos was used as the analytics tool. The variables are granular with the drill down capability for details on country level development. The data was extracted, transformed, and loaded into an IBM DB2 database for processing. Cognos Framework Manager was used to transform the data into cubes. The cubes were published into a package that was then loaded into Cognos Query and Report Studios for analysis and reporting. The data set is comprehensive and longitudinal and allows in-depth analyses.

We based our research on the following premises:

- Patent applications are good indicators of the level of innovation (Granstrand 2005).

- Patent applications are only applied through Patent Cooperation Treaty (PCT).

- The International Patent Classification (IPC) for industries offers a sound basis for analyzing data.

- Patent application date is a good reference point and can be used like the application priority date.

- Every patent application has a reasonable success rate.

We analyzed the data to address our research question: What are the key economic factors that determine the success of innovation at a country level? The following section discusses the results of our analyses.

\section{Results and discussion}

Number of patent applications under PCT

We first analyzed the sample of OECD countries for the number of patent applications under PCT, to detect variations, if any. The analysis reflects a wide variation in the number of patent applications. Figure 1 shows the distribution for the countries for the year 2010.

\begin{tabular}{|c|c|c|}
\hline \multicolumn{3}{|c|}{$\begin{array}{l}\text { Year: } 2010 \\
\text { A } \neq \text { Patent Application under PCT: Descending order }\end{array}$} \\
\hline Country & Year & Patent Application under PCT $\checkmark$ \\
\hline United States & 2010 & 87318.77 \\
\hline Japan & 2010 & 63981.51 \\
\hline Germany & 2010 & 34561.64 \\
\hline Korea & 2010 & 18165.47 \\
\hline France & 2010 & 14709.46 \\
\hline United Kingdom & 2010 & 9059.07 \\
\hline Switzerland & 2010 & 7806.77 \\
\hline Netherlands & 2010 & 7703.20 \\
\hline Sweden & 2010 & 6561.50 \\
\hline Italy & 2010 & 5201.50 \\
\hline Canada & 2010 & 4685.40 \\
\hline Finland & 2010 & 4098.47 \\
\hline Spain & 2010 & 3407.65 \\
\hline Australia & 2010 & 3357.23 \\
\hline Israel & 2010 & 2865.85 \\
\hline Austria & 2010 & 2290.33 \\
\hline Denmark & 2010 & 2224.83 \\
\hline Belgium & 2010 & 2090.90 \\
\hline Norway & 2010 & 1418.00 \\
\hline Ireland & 2010 & 967.36 \\
\hline
\end{tabular}

Fig. 1 Distribution of patent applications under PCT by country for 2010 
As seen in Fig. 1, countries such as the USA, Japan, Germany, Korea, and France have a high number of patent applications under PCT $(>10,000)$ indicating a significant level of innovation. Interestingly, even though there are only two Asian countries in the sample-Japan and Korea-both rank high in innovation. To get an idea of the sustainability of innovation over the years, we compared our 2010 ranking with Bloomberg's ranking of innovative countries by patents for the year 2015 (Bloomberg 2015). The top countries in our analyses were also among the top 10 in Bloomberg's list in terms of number patent applications, showing that the innovation level sustained over the 5 years following the research. For further meaningful comparisons, future analyses should consider weighting the patent applications for each country based on the population of the country.

We then explored the patents by industry to observe whether some industries were more innovative than others. Figure 2 displays the industry classifications and the number of patent applications for each classification for the year 2010.

Figure 2 displays the sector/industry ranking by number of patent applications. The lower-ranked industries (number of applications <5000) are highlighted in red and the higher-ranked (number of applications $>10,000$ ) in green. Industries-including textiles, paper, and fixed constructions-show a low number of patent applications compared to industries such as electricity and physics. Most countries tend to focus on the latter type of industries, referred to as sunrise industries because they show more potential for innovation. Breakthrough innovations in electricity and physics, such as electromagnetism or nuclear physics, have led to transformational developments in modern television, computers, and household appliances, and so it is inevitable that associated industries should introduce a high level of innovation. The number of patent applications for performing operations and transporting is also high. Human necessities, an industry category with a high number of patents, include the industries of agriculture, personal or domestic health articles, foodstuffs, and amusement. Countries looking to stimulate innovation should focus on industries that show potential for development and entrepreneurship.

\section{R\&D expenditure per capita}

In order to understand the level of economic development in these countries, we looked at Research \& Development (R\&D) expenditure per capita for a single year,

\begin{tabular}{|c|c|c|}
\hline Patent by Technology & Year & Patent Application under PCT $\nabla$ \\
\hline Electricity & 2010 & 31500.51 \\
\hline Physics & 2010 & 26506.75 \\
\hline Human Necessities & 2010 & 26406.39 \\
\hline Chemistry; Metallurgy & 2010 & 20153.22 \\
\hline Performing Operations; Transporting & 2010 & 20125.11 \\
\hline Mechanical Engineering; Lighting; Heating; Weapons; Blasting & 2010 & 13132.01 \\
\hline Fixed Constructions & 2010 & 4237.75 \\
\hline Textiles; Paper & 2010 & 1459.54 \\
\hline \multicolumn{2}{|l|}{ Summary } & 143521.29 \\
\hline
\end{tabular}

Fig. 2 Distribution of the number of patent applications by industry for 2010 
2010 (Fig. 3). The R\&D expenditure per capita was calculated using the GPD per capita and expenditure/GDP, as shown.

Figure 3 shows that, for 2010, Finland ranks first with the highest R\&D expenditure per capita, followed by Sweden, Denmark, and Austria. The large R\&D expenditure in Finland can be attributed in part to its headquartering Nokia, the multinational ICT (information and communication technology) company that pioneers innovative technology. These findings are consistent with Bloomberg's 2015 global innovation ranking of countries based on R\&D expenditure (Bloomberg 2015). Sweden and Finland also were among the top five innovative countries in Bloomberg's ranking. On the other hand, Germany, which is sixth in our ranking, does not figure among the top six in Bloomberg's 2015 ranking. It may come as a surprise that, in terms of R\&D expenditure, the USA does not figure among the top countries in either our analysis or in Bloomberg's.

We expected countries that rank high in R\&D expenditure to also be the most innovative. However, Finland, Sweden, Denmark and Austria, which are the top ranked countries for R\&D as shown in Fig. 3, do not rank among the top innovative countries shown in Fig. 1. An explanation for this could be the fact that while some countries innovate by increasing their investment in R\&D, others do so by utilizing the know-how already generated by other countries (Guloglu and Tekin 2012). Furthermore, R\&D is only one of the indicators for innovation; others include institutional and social regulations, education of the workforce, and technical skills of the workforce. Therefore, it is possible to innovate by way of measures other than $R \& D$ expenditure.

Tax revenue as a percentage of GDP and patents owned by foreign residents

At a country level, tax revenue is an important indicator of economic development. We felt it is important to analyze whether a country's tax revenue as a percentage of GDP

\begin{tabular}{|c|c|c|c|c|c|}
\hline Continent & Year & County & GDP per capita (US\$) & Expenditure/GDP & GDP per capita (US\$) * Expenditure/GDP \\
\hline Europe & 2010 & Finland & 181,535 & 0.0781 & 14177.88 \\
\hline Europe & 2010 & Sweden & $196,727.95$ & 0.0678 & 13338.16 \\
\hline Europe & 2010 & Denmark & $200,949.4$ & 0.0614 & 12338.29 \\
\hline Europe & 2010 & Austria & $200,324.2$ & 0.0558 & 11178.09 \\
\hline Europe & 2010 & Luxembourg & $345,077.4$ & 0.0296 & 10214.29 \\
\hline Europe & 2010 & Germany & $149,720.36$ & 0.056 & 8384.34 \\
\hline Europe & 2010 & Norway & $229,037.8$ & 0.0336 & 7695.67 \\
\hline Europe & 2010 & France & $171,281.35$ & 0.0447 & 7656.28 \\
\hline Europe & 2010 & Belgium & $188,639.2$ & 0.0401 & 7564.43 \\
\hline Europe & 2010 & United Kingdom & 178,434 & 0.036 & 6423.62 \\
\hline Europe & 2010 & Netherlands & $168,782.28$ & 0.0371 & 6261.82 \\
\hline Europe & 2010 & Slovenia & 134,705 & 0.0418 & 5630.67 \\
\hline Europe & 2010 & Ireland & $161,912.52$ & 0.0341 & 5521.22 \\
\hline Europe & 2010 & Spain & 159,519 & 0.0278 & 4434.63 \\
\hline Europe & 2010 & Portugal & $127,221.45$ & 0.0317 & 4032,92 \\
\hline Europe & 2010 & Italy & $159,555.5$ & 0.0252 & 4020.80 \\
\hline Europe & 2010 & Czect Republic & $126,289.2$ & 0.031 & 3914.97 \\
\hline Europe & 2010 & Estonia & $101,966.45$ & 0.0326 & 3324.11 \\
\hline Europe & 2010 & Hungary & $82,222.44$ & 0.0232 & 1907.56 \\
\hline Europe & 2010 & Slovak Republic & $116,318.2$ & 0.0126 & 1465.61 \\
\hline
\end{tabular}

Fig. 3 R\&D expenditure per capita for 2010 
has any association with innovation in terms of patents owned by foreign residents (Fig. 4).

As shown in Fig. 4, we calculated an index using the ratio of patents owned by foreign residents and the tax revenue as a percentage of GDP, in order to obtain a comparative assessment for each country. We show benchmarks for the variables. For the ratio of patents owned by foreign residents, values under 10 are highlighted in red to indicate poor performance, and values over 20, in green to indicate high performance. For tax revenue as percentage of GDP, values above 200 are highlighted in yellow to denote good performance. For the index, values under 0.12 are highlighted in red to indicate poor performance while values over 0.12 are highlighted in green to indicate good performance. Figure 4 shows that countries such as Sweden, France, Finland, and Austria have high tax revenues as percentage of GDP but show a low ratio of patents owned by foreign residents. On the other hand, countries such as Luxembourg and Iceland with low tax revenue as a percentage of GDP have a higher ratio of patents owned by foreign residents. There seems to be an inverse association between tax revenue (as a percentage of GDP) and patents owned by foreign residents. Countries with high foreign ownership of patents experience a decrease in tax revenues. This is a relevant finding on patents/IP and it has important implications that will be discussed in the "Conclusions" section.

\section{Real minimum wage and PCT patent applications per 10,000 inhabitants}

We looked to see whether real minimum wages (as an economic indicator) has any relationship with innovation indicated by PCT patent applications per 10,000 inhabitants (Fig. 5). Real hourly and annual minimum wages are statutory minimum wages converted into a common hourly and annual pay period (in US\$) for the OECD countries

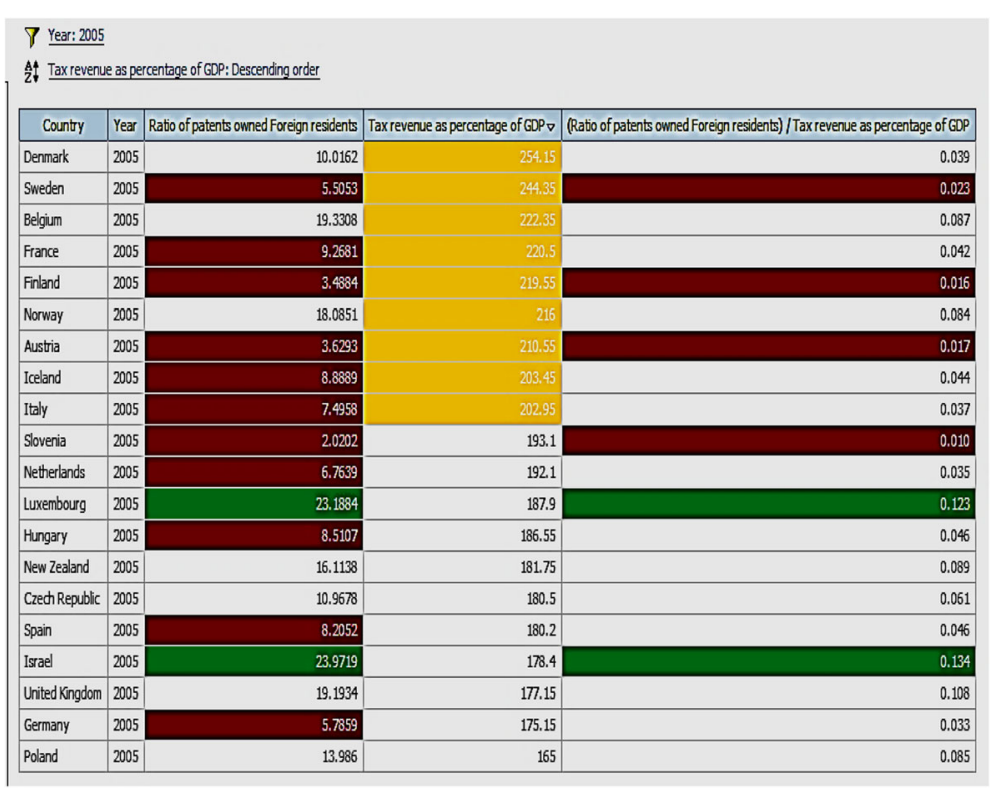

Fig. 4 Tax revenue as a percentage of GDP and patents owned by foreign residents 


\begin{tabular}{|c|c|c|c|}
\hline Year & County & Real Min Wage $\nabla$ & PCT patents applications per 10,000 inhabitants \\
\hline 2008 & Netherlands & $27,374.46$ & 2.17 \\
\hline 2008 & Belgium & $26,510.56$ & 1.02 \\
\hline 2008 & Ireland & $25,857.88$ & 0.97 \\
\hline 2008 & France & $24,350.08$ & 1.11 \\
\hline 2008 & United Kingdom & $23,999.89$ & 0.98 \\
\hline 2008 & Canada & $17,273.34$ & 0.78 \\
\hline 2008 & Japan & $13,633.05$ & 1.99 \\
\hline 2008 & United States & $13,582.12$ & 1.43 \\
\hline 2008 & Spain & $13,174.55$ & 0.36 \\
\hline 2008 & Greece & $13,099.21$ & 0.1 \\
\hline 2008 & Slovenia & $10,767.05$ & 0.7 \\
\hline 2008 & Korea & $10,351.71$ & 1,46 \\
\hline 2008 & Portugal & $9,442.18$ & 0.13 \\
\hline 2008 & Poland & $6,443.7$ & 0.05 \\
\hline 2008 & Czech Republic & $6,025.01$ & 0.2 \\
\hline 2008 & Hungary & $5,815.24$ & 0.22 \\
\hline 2008 & Estonia & $5,484.9$ & 0.34 \\
\hline 2008 & Slovak Republic & $5,066.27$ & 0.06 \\
\hline 2008 & Chile & $3,763.74$ & 0.03 \\
\hline 2008 & Mexico & $1,409.54$ & 0.02 \\
\hline \multicolumn{2}{|c|}{ Summary } & $263,424.48$ & 14.12 \\
\hline
\end{tabular}

Fig. 5 Real minimum wage and PCT patent applications

for which they are available. The numbers are deflated by the national Consumer Price Indices $(\mathrm{CPI})$.

Figure 5 lists the countries in descending order of real minimum wages (in US\$). The values of PCT patent applications per 10,000 inhabitants that are above 1.0 are highlighted. The countries of Netherlands, Belgium, and Ireland have the highest real minimum wages. These countries also have an elevated number of patent applications per 10,000 inhabitants. Countries like Mexico, Chile, Estonia, and the Slovak Republic have low real minimum wages and a correspondingly low number of PCT patent applications per 10,000 inhabitants. There is a positive association between real minimum wages and the number of patent applications, in that the higher the real minimum wages, the higher the level of innovation reflected by patent applications. Thus, countries that foster higher standards of living and better work conditions (through higher minimum wages) also foster more innovation and growth. Korea is an exception in that it has a high level of patent applications despite an average minimum wage. This phenomenon can be attributed to it being the headquarters for Samsung, the multinational telecommunication giant. In terms of patents, our rankings are consistent with the 2015 ranking of Bloomberg's innovative countries (Bloomberg 2015) thereby demonstrating that these countries have sustained their innovation over the years 2010 to 2015.

\section{Labor cost in different industry categories}

To identify any significant patterns, we analyzed labor costs by industry for all European countries in our sample (Fig. 6). The labor cost for an industry encompasses direct and indirect costs including employee wages, employee benefits, and payroll taxes of employers. 


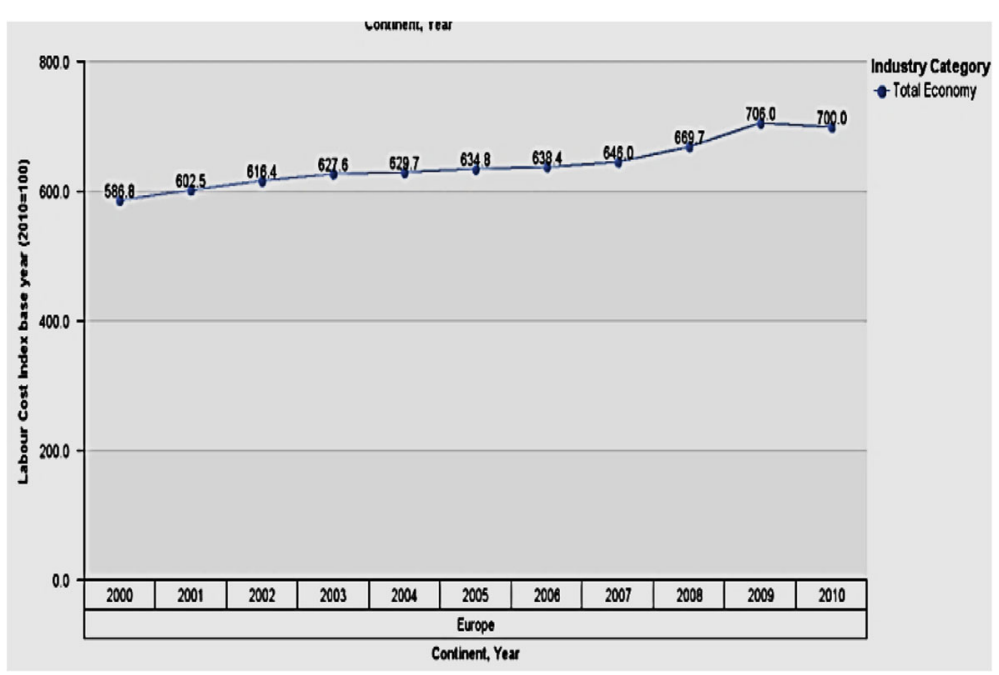

Fig. 6 Distribution of labor cost by industry for countries in Europe

It is important to analyze this component as the costs vary depending on the nature of the industry. For example, costs for manufacturing vary from that for service industries due to the nature of tasks and activities.

Figure 6 shows a 9.3\% increase in overall labor cost for the European countries between the years 2000 and 2010. With the exception of a small decrease in total cost between the years 2009 and 2010, the general trend in labor cost is upward. To ascertain which industries contributed most to cost increases, we broke down costs by industry (Fig. 7).

Figure 7 shows that of all the industries construction has a significant contribution to the increase in labor cost over time. From our earlier analysis on the number of patent applications by industry (shown in Fig. 2), construction showed a less-than-average number of patent applications per 10,000 inhabitants. It appears that there is a negative association between labor cost and number of patent applications. The higher the labor cost, the lower the number of patent applications, suggesting that countries should contain the cost of labor in order to stimulate innovation and growth.

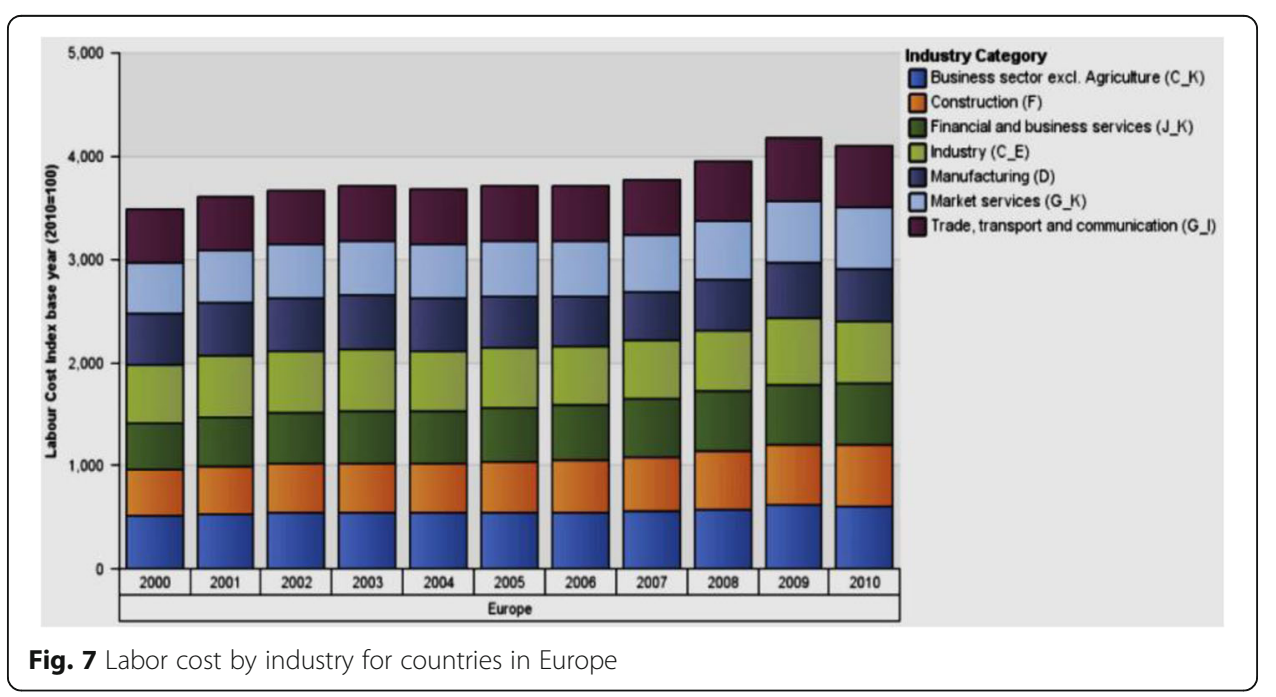




\section{Ratio of education enrollment to total population}

Because education is an important indicator for any economy, we chose to investigate whether education plays a role in country level innovation. In order to draw meaningful comparisons on the state of education enrollment, we calculated a ratio of education enrollment to total population for each country. The ratio is shown for the countries in the continents of Asia, Europe, North America, and South America (Fig. 8). From these continents, we selected Europe to show the annual variation in the ratio of enrollment to population and used a line chart to depict our findings (Fig. 8).

As seen in Fig. 8, for all the continents, the ratio of education enrollment is highest at the elementary level followed by that at the secondary level. Enrollment at the tertiary level is highest in North America, where it is almost equal to the enrollment at the secondary level. We see, looking at the trend line for the ratios for the years 2000 to 2010, that enrollment at the secondary and tertiary levels are increasing without a corresponding increase at the elementary level. One possible explanation for this trend is that more adults are returning to school to complete their secondary and tertiary education. In terms of institutions and facilities, access to higher-level education has increased across Europe over the years. The education sector, in general, has expanded to include diverse options relative to content, pedagogy, and methodologies. This expansion has opened up a vista of alternatives to traditional college education, including online/hybrid courses as well as vocational and technical certification programs. As a result, young people today may achieve a higher education level than prior generations. According to the 2012 Survey of Adult Skills, about 32\% of 25- to 34-year-olds show upward mobility. That is, they have a higher level of education than their parents (OECD 2014).

Was there an association between education enrollment and the innovation (number of patent applications) at country level for the years 2000 to 2010? We investigated this question next.

Figure 9 shows a table of the countries with the highest number of patent applications and a line chart depicting countries with the highest ratios of education enrollment to total population. The top three innovative countries (with the most patent applications) for the years 2009 and 2010 are USA, Japan, and Germany. However, out of these countries, we see that only the USA has a high ratio of education enrollment

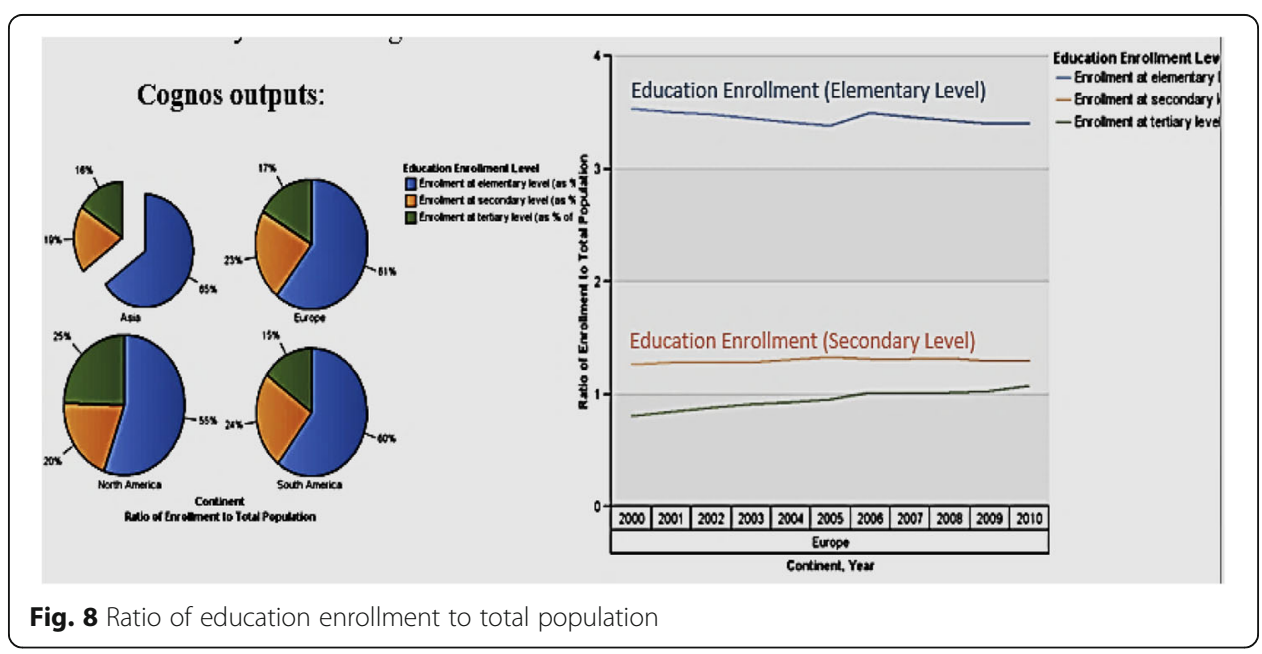




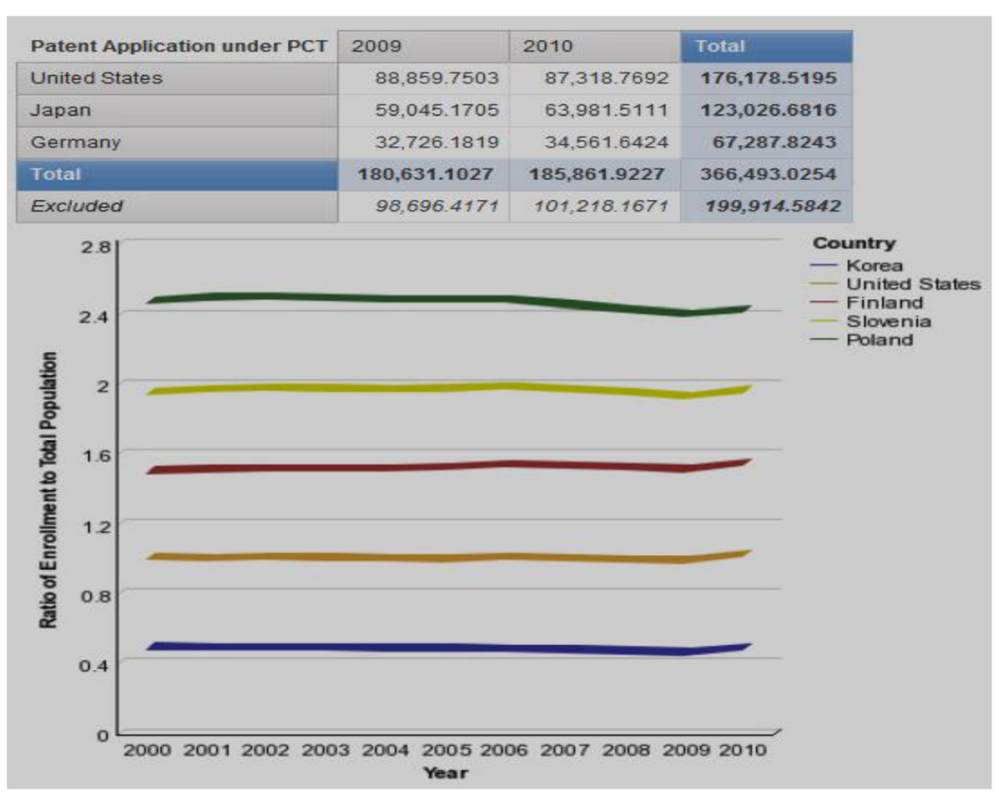

Fig. 9 Ratio of education enrollment and number of patent applications under PCT

to total population (as seen in the line chart). Poland and Slovenia have high education enrollment but do not figure among the top innovative countries. It appears that there is no direct association between education enrollment and innovation.

High education enrollment does not necessarily indicate high innovation. Even though education, learning, and knowledge are integral for creative thinking and innovation, transforming creative ideas into innovation is contingent upon environmenal components (Fagerberg and Srholec, 2008) as well as the way in which education is fostered (Sawa 2016). Some innate skills required for innovation include the ability to think, make judgments, and express oneself. To facilitate innovative tendencies, education systems need to instill in students critical thinking and communication skills. In some countries such as the USA, the undergraduate curriculum in universities is designed with an emphasis on liberal arts education which teaches students to synthesize disparate ideas into creative, unified solutions. This type of education offers a good foundational framework for innovation. While the liberal arts undergraduate curriculum focuses on empowering basic skills, a graduate curriculum delivers specialized skills that directly relate to future jobs. In other countries like Japan, the undergraduate curriculum does not emphasize the critical thinking skills, focusing instead on quantitative skills (Sawa 2016; Shin and Zhou 2007). Quantitative skills are important of course, but they need to be balanced with the liberal arts skills of thinking and communicating. Thus, the quality of education is important.

We examined education enrollment at the tertiary level in Europe to study possible associations with innovation (number of patent applications). Figure 10 shows the association for the continent of Europe.

Figure 10 shows that, for Europe, as the enrollment in tertiary level increases, the number of patents (innovation) also increases (except between the years 2007 and 2008). It appears that, in Europe, higher (tertiary) education stimulates innovation by endowing citizens with the requisite skills sets that are required. Also, in Europe, more resources are allocated to higher (tertiary) education, thus enabling the population to 


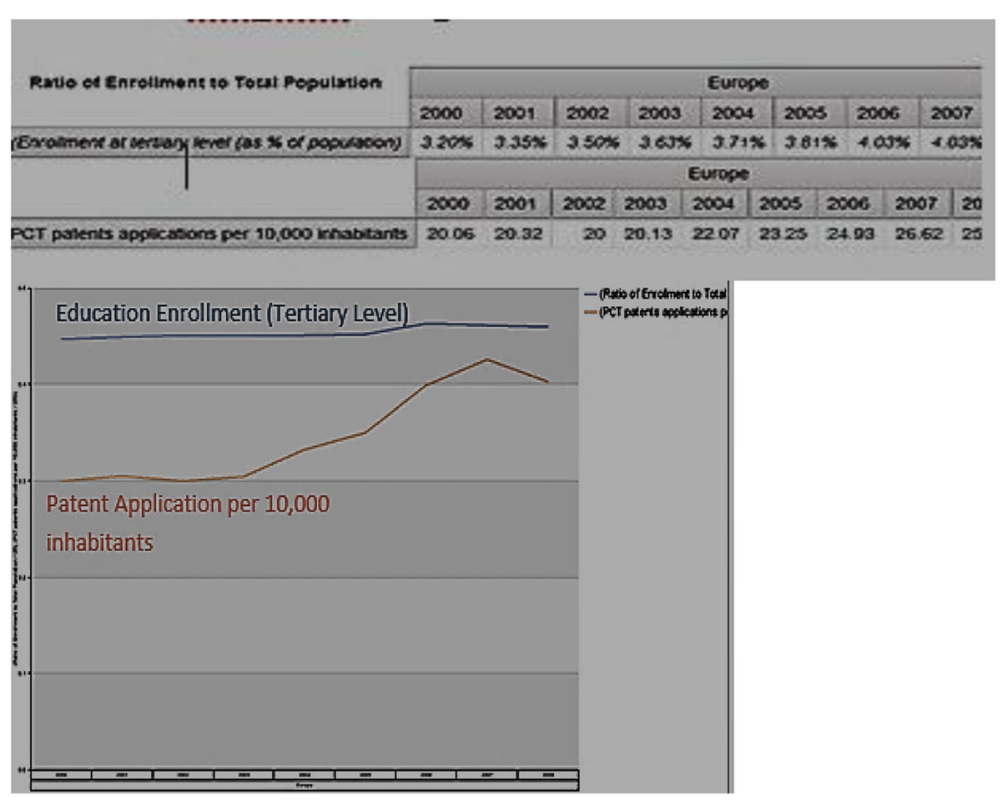

Fig. 10 Education enrollment at tertiary level and PCT patent applications per 10,000 inhabitants

explore innovative endeavors. These findings suggest that governments looking to promote innovation can invest more in higher education, allocating more resources and facilities that encourage the pursuit of high-level studies. Our analysis, however is limited to Europe; future studies may analyze the differences between continents in terms of the relationship between tertiary or secondary education and innovation.

\section{Patents owned by foreign and domestic residents}

We analyzed the proportion of patents owned by foreign versus domestic residents for countries in Europe for the year 2005 (Fig. 11).

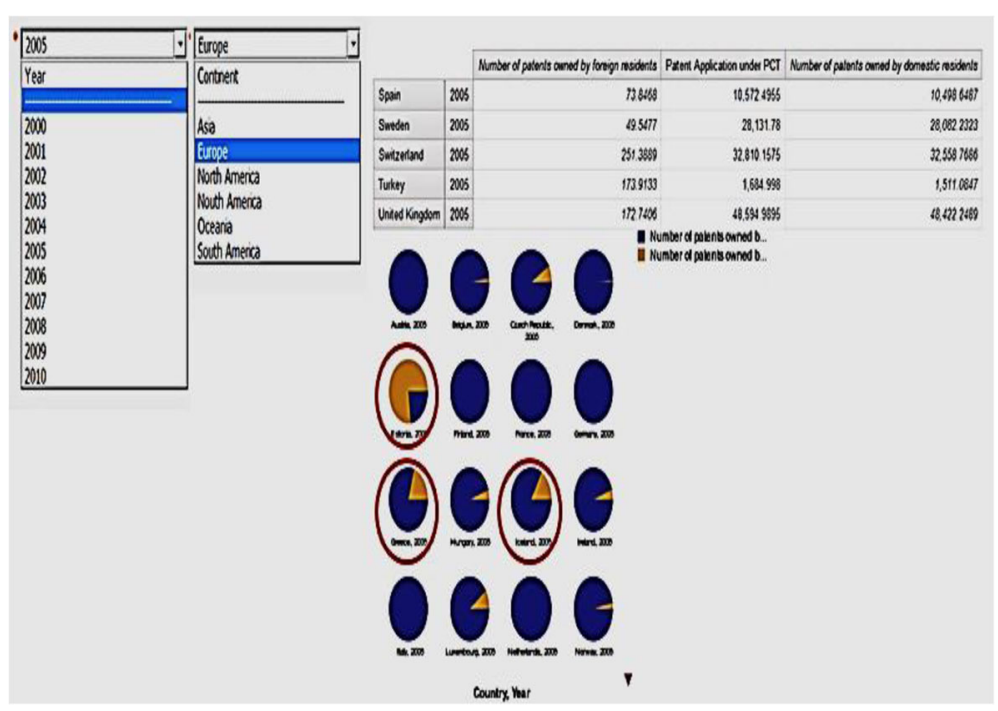

Fig. 11 Comparison of patents owned by foreign residents vs. domestic residents in Europe for 2005 
Figure 11 shows the proportion of patents owned by foreign residents and that owned by domestic residents for each country in Europe for one year, 2005. From the pie charts, we see that Estonia, Greece, and Iceland have more patents held by foreign residents (these are circled).

To encourage and stimulate more innovation by local residents, countries like these should put in place the appropriate policies and resources to do so. In addition, these countries should focus on improving their educational systems so that they offer the relevant skills and knowledge to foster innovation and growth. The findings on patent holdings by foreign versus domestic residents hold implications for policies on taxation and ownership of patents. These findings are discussed in detail in the "Conclusions" section.

\section{Average of economic indicators (GDP/GNI/real minimum wages) and patents owned by foreign residents}

We analyzed the association between the average of economic indicators (GDP, GNI, and real minimum wages) and percentage of patents owned by foreign residents. We expected that the more developed an economy (higher average of GDP, GNI, and real minimum wages), the lower the percentage of patents owned by foreign residents (Fig. 12).

Figure 12 shows that countries with a low average of economic indicators have a high percentage of patents owned by foreign residents. These countries rely on foreign collaboration to strengthen their resources and facilities for innovations. These crossborder collaborations often result in patent ownership by foreign residents instead of locals. On the other hand, countries that have a developed economy-characterized by high GDP, GNI, and real minimum wages-have more local resources and talent, and therefore do not rely on foreign collaboration. This leads to a high proportion of patents owned domestically and a low proportion of patents owned by foreigners.

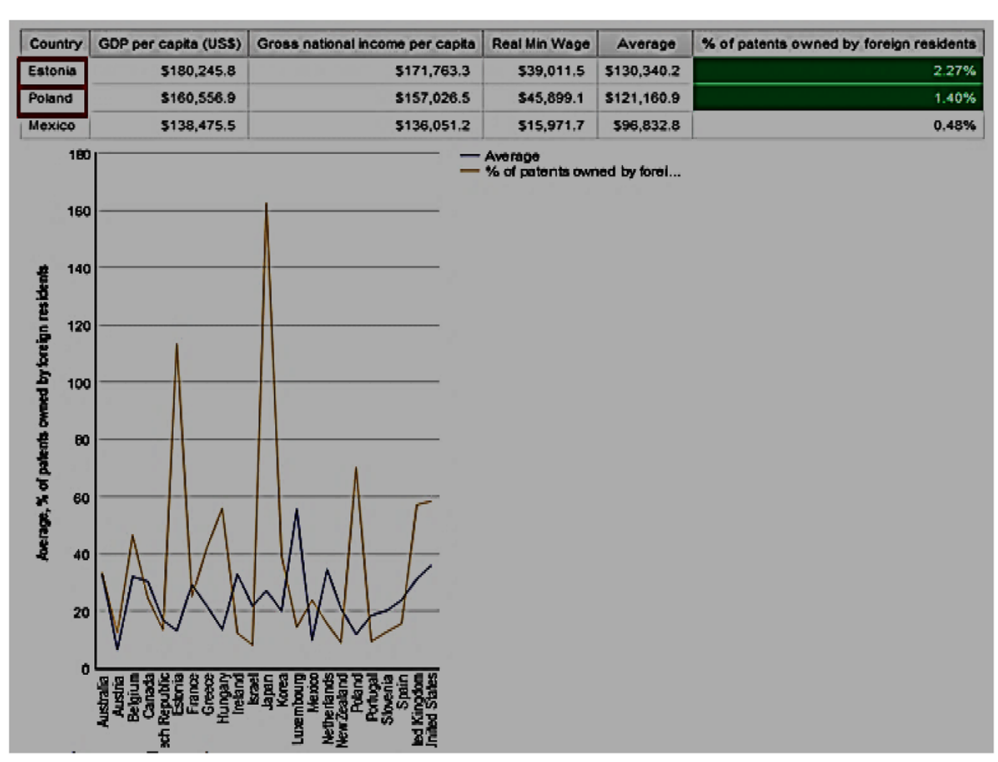

Fig. 12 Economic indicators and patents owned by foreign residents 
For the countries Estonia, Iceland, and Greece, which show the highest percentage of foreign-owned patents as illustrated in Fig. 11, we analyzed the number of patents under PCT by industry (Fig. 13). We were curious to see whether there is a pattern showing that certain industries dominate the category of patent ownerships by foreign residents. We selected 2003 for analysis.

Figure 13 shows that for Greece, Iceland, and Estonia, the industry with the most foreign owned patent applications is performing/operations/transporting followed by mechanical engineering. This finding indicates that local talent in these sectors is insufficient, creating a dependency by the economy on foreign talent. One solution to this dependence would be to enhance education that specifically addresses requirements in these sectors. More local residents should be able to acquire knowledge and skills that encourage innovation internally. In addition, the government in these countries should introduce measures to promote innovations in these sectors.

\section{R\&D expenditure by sector and patent applications}

We had analyzed overall R\&D expenditure per capita (Fig. 3) for all the countries. To identify significant patterns within particular sectors, we then explored the R\&D expenditure by sector (government, business, higher education, and private and nonprofit sector) for the continent of Europe (Fig. 14).

Figure 14 shows that government and higher education sectors in Europe have higher $R \& D$ expenditures than private and non-profit sectors. To reverse this trend, European

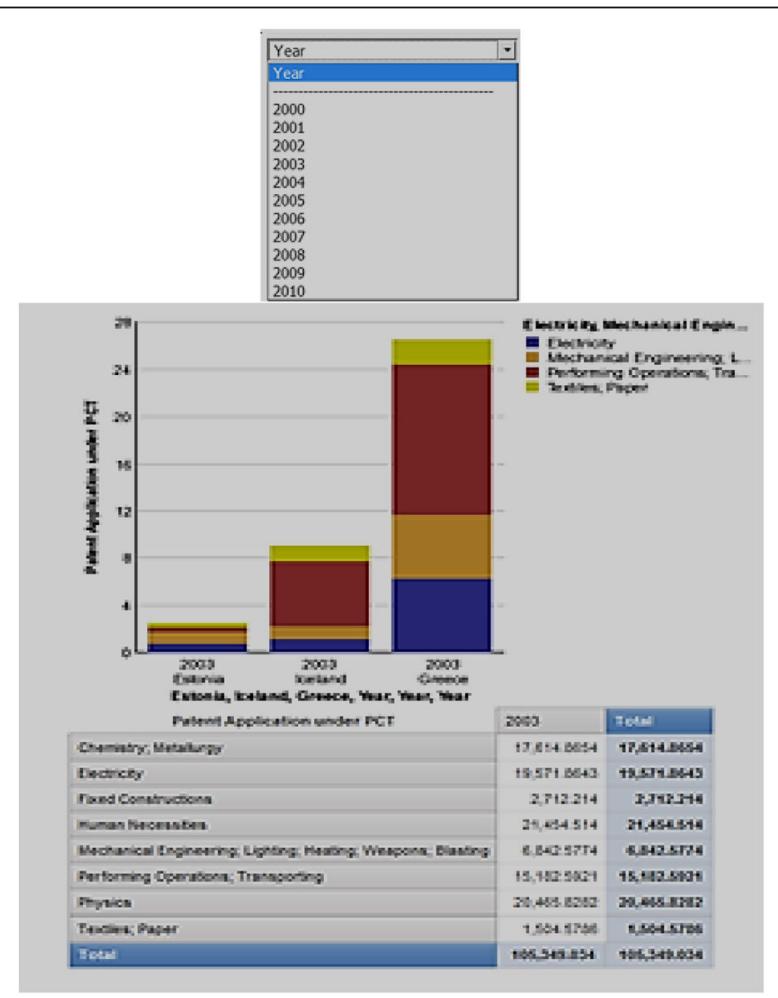

Fig. 13 Patents under PCT by industry for countries with high percentage of patents owned by foreign residents 


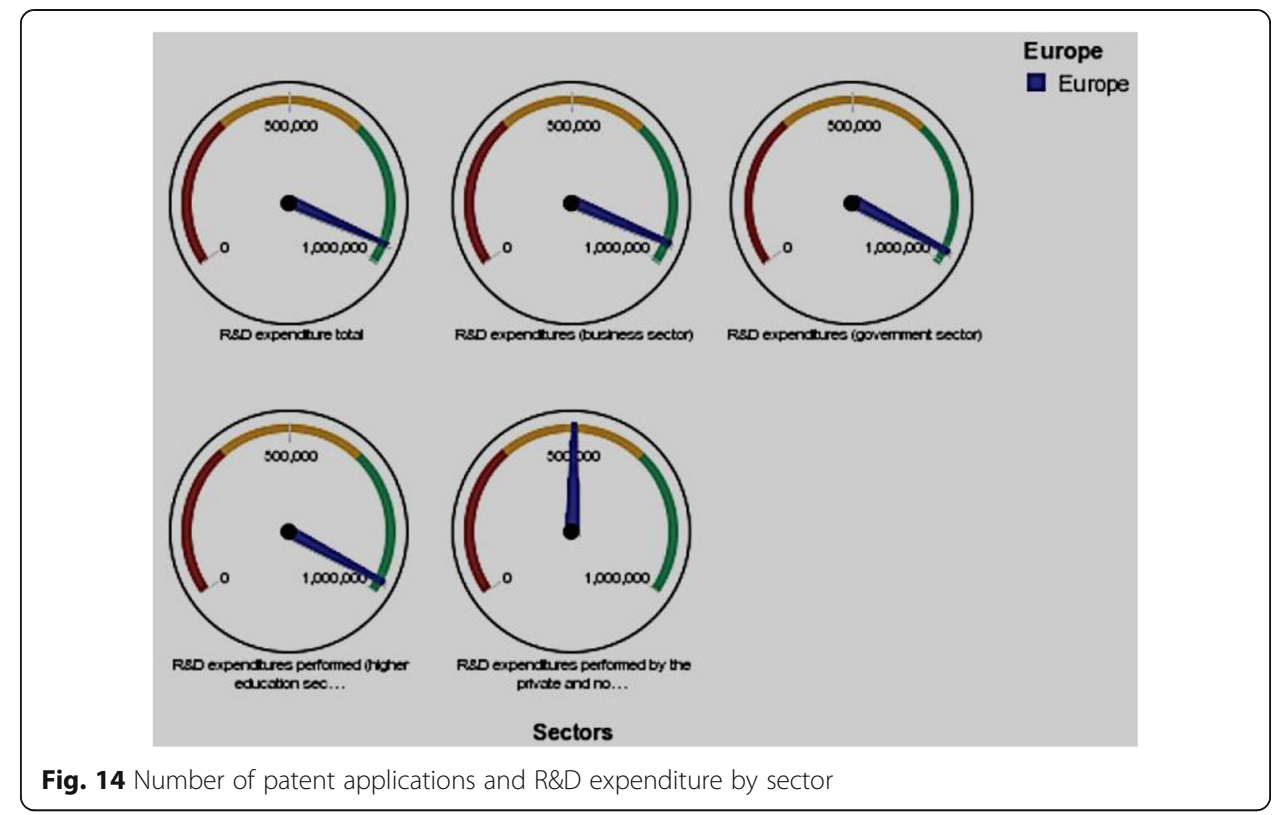

countries in this sample should advocate policies that encourage more innovation in the private and non-profit sectors.

\section{Scope and limitations}

There are some limitations to our study. First, although we cover a reasonable time span of 10 years, future studies can cover a longer span thereby increasing the possibility of highlighting more trends and patterns. Second, using analytics, our study looks at associations but does not investigate causality in the relationship between economic and innovation indicators. Third, we only consider a small segment of economic and innovation indicators. Obviously, other and more variables could be considered and included for future research. Our data is from a secondary data source (OECD), which is an aggregated set from multiple models and sources and therefore subject to limitations. Finally, we deploy a health analytics approach to investigate the relationship between economic indicators and innovation. Other studies could explore alternate approaches, theories, and models.

\section{Conclusions}

Despite its limitations, our study makes several important contributions to literature on innovation and economic growth at a national level. Whereas most studies on innovation focus on firm-level or enterprise-level innovation, our study analyzes country-level innovation. In addition, it incorporates a comprehensive and large data set from OECD that allows for longitudinal analyses.

We also contribute in terms of the methodology of analytics used in the research. This emerging technique offers potential in various domains including innovation. We demonstrate how data-driven analytics can help make informed decisions on innovation and economic growth. The research adds to the empirical studies literature on innovation that deploy an analytic approach. 
By identifying a portfolio of economic factors that influence innovation, we offer insights policy makers may call upon to design effective policies targeted toward promoting and encouraging innovation. Our analysis of industries with the most potential for innovation offers benchmarks for effective resource allocation or incentive assignment in fecund industries. Incentives can take the form of subsidies, tax breaks, grants, or business incubation services that facilitate innovation. In addition, our results offer benchmarks for efficient resource allocation among industries.

The relationship between R\&D expenditure and innovative efforts of a country has been emphasized by endogenous growth models (Romer 1994; Zachariadis 2003). In this regard, we show that while $R \& D$ is an important indicator for innovation, only some OECD countries innovate by increasing their investment in $R \& D$. Others promote their innovation through technology spillovers from other OECD countries (Acemoglu and Linn 2004; Wang 2010). These countries utilize the know-how that is generated by other countries (Guloglu and Tekin 2012). This finding does not mean that R\&D is not important for long-term growth. Instead, it implies that the measure of $R \& D$ cannot be interpreted as a complete measure of innovation: other factors must be considered (Aghion and Howitt 1998).

On a socio-economic level, our findings on the association between the standard of living (real minimum wages, labor cost) and innovation suggests that to improve innovation and economic growth, countries need to focus on improving the standard of living in terms of high minimum wages, low labor cost, and better work conditions.

A notable contribution of our research lies in the dimension of internationalization and ownership of technology innovation (patents). We show that countries with high foreign ownership of patents have low tax revenues as a percentage of GDP. An exploration of the concept of income from intellectual property (IP) is helpful in interpreting this association further. In general, income from IP is mobile because it has no associated trade costs (Griffith et al. 2014). Thus, patent ownership may be found in locations other than the country in which they were created. Multinational companies, a big source for patents, typically exploit this mobility by locating their intellectual property in low-tax countries (referred to as tax havens) thereby decreasing their tax burden (Lipsey 2010). It's no wonder that countries that see a high proportion of patents owned by foreign residents have grown increasingly concerned about the tax revenue losses arising from such relocation schemes. To address this, some countries have introduced patent boxes to reduce the tax rate on income derived from patents. Belgium, for example, introduced a patent box in 2007, reducing the tax rate from 34 to $6.8 \%$. The Netherlands reduced the tax rate from 31.5 to $10 \%$. In 2008, Luxembourg reduced the rate from 30.4 to $5.9 \%$; and in 2013, the UK introduced a patent box at the rate of $10 \%$ reducing the tax rate from 30 to $24 \%$ (Griffith et al. 2014). We suggest that countries should address the ownership of patents and encourage more ownership by local residents and less by foreign residents, in order to increase innovation and boost tax revenues that result in economic growth.

In terms of education in influencing innovation, we highlight the importance of having an integrated curriculum that offers students the liberal arts skills (analytical, evaluative, critical and creative thinking, and written and oral communication) as well as quantitative and technical skills needed for the workplace. Most employers want 
employees to have the ability to learn and synthesize new ideas, be reflective and articulate, and have excellent organization and time-management skills. We reinforce the need for governmental policies to focus on enhancing the quality of education to facilitate the knowledge transfer needed for country-level innovation. Proposing a regulatory framework to promote innovation is a challenging task because, in addition to economic growth, this framework has to address social and environmental goals. More theoretical and empirical research is needed. Another important direction for future work is analysis of the impact of other forms of intellectual property-copyrights and trademarks in addition to patents- on economic growth and innovation.

\section{Funding}

There was no funding for the research.

Availability of data and materials

The dataset supporting the conclusions of this article are available in the OECD repository, http://stats.oecd.org/

\section{Authors' contributions}

Both the authors contributed equally to the manuscript. Both authors read and approved the final manuscript.

\section{Competing interests}

The authors declare that they have no competing interests.

\section{Authors' information}

Viju Raghupathi is presently an Assistant Professor of Business at Koppelman School of Business, Brooklyn College of the City University of New York. She received her PhD in Information Systems from The Graduate Center, City University of New York. Her research interests include innovation, healthcare, business analytics, social media, sustainability, and corporate governance. She has published in Communications of the AIS, Journal of Electronic Commerce Research, Journal of Health and Medical Informatics, International Journal of Healthcare Information Systems and Informatics, Health Policy and Technology, Information Resources Management Journal, and Information Systems Management.

Wullianallur Raghupathi is Professor of Information Systems at Gabelli School of Business, Fordham University, New York, Program Director of the M.S. in Business Analytics Program, and Director of the Center for Digital Transformation (http://www.fordhamcdt.org/). He received his PhD in Information Systems from the University of Texas at Arlington. $\mathrm{He}$ is co-editor for North America of the International Journal of Health Information Systems \& Informatics. He has guest edited a special issue of Topics in Health Information Management (1999) and a special section on healthcare information systems for Communications of the ACM (1997). He has 40 refereed journal publications, several conference proceedings, book chapters, editorials, and reviews including many in healthcare IT.

\section{Author details}

${ }^{1}$ Koppelman School of Business, Brooklyn College of the City University of New York, 2900 Bedford Ave, Brooklyn, NY 11210, USA. 'Gabelli School of Business, Fordham University, 140 W. 62nd Street, New York, NY 10023, USA.

Received: 26 October 2016 Accepted: 31 January 2017

Published online: 27 February 2017

References

Acemoglu, D.J. Linn, D. (2004) Market Size in Innovation: Theory and Evidence from the Pharmaceutical Industry. The Quarterly Journal of Economics 119 (3):1049-1090.

Aghion, P., \& Howitt, P. (1998). Endogenous growth theory. Cambridge, Massachusetts: MIT Press.

Angle, H. L. (2000). Psychology and organizational innovation. In A. H. Van \& de Ven (Eds.), Research on the management of innovation. The Minnesota studies (pp. 135-171). Oxford, UK: Oxford University Press.

Atun, R. A., Harvey, I., \& Wild, J. (2007). Innovation, patents and economic growth. International Journal of Innovation Management, 11(2), 279-297.

Blind, K., Bührlen, B., Kotz, C., Menrad, K., \& Walz, R. (2004). New products and services: analysis of regulations shaping new markets. Luxembourg: European Commission DG Enterprise.

Bloomberg (2015). The Bloomberg Innovation Index 2015. http://www.bloomberg.com/graphics/2015-innovativecountries. Accessed 20 January 2016.

Fagerberg, J., \& Srholec, M. (2008). National innovation systems, capabilities, and economic development. Research Policy, 37, 1417-1435.

Ginarte, J., \& Park, W. G. (1997). Determinants of patent rights: a cross-national study. Research Policy, 26(3), $283-301$.

Granstrand, O. (2005). Innovation and intellectual property rights. In J. Fagerberg, D. C. Mowery, R. R. Nelson (Eds), The Oxford Handbook of Innovation. Oxford University Press.

Griffith, R., Miller, H., \& O'Connell, M. O. (2014). Ownership of intellectual property and corporate taxation. Journal of Public Economics, 112, 12-23.

Guloglu, B., \& Tekin, R. B. (2012). A panel causality analysis of the relationship among research and development, innovation, and economic growth in high-income OECD countries. Eurasian Economic Review, 2(1), 32-47. 
Hsu, C., Tana, K. C., Jayaramb, J., \& Laosirihongthongc, T. (2014). Corporate entrepreneurship, operations core competency and innovation in emerging economies. International Journal of Production Research, 55(18), 5467-5483.

Hudson, J., \& Minea, M. (2013). Innovation, intellectual property rights, and economic development: a unified empirical investigation. World Development, 46, 66-78

Huelsheger, U. R., Anderson, N. R., \& Salgado, J. F. (2009). Team-level predictors of innovation at work: a comprehensive meta-analysis spanning three decades of research. The Journal of Applied Psychology, 94, 1128-1145.

Kanwar, S., \& Evenson, R. (2003). Does intellectual property protection spur technological change? Oxford Economic Papers, 55(2), 235-264.

Kim, Y. K., Lee, K., Park, W.G. (2008). Appropriate intellectual property protection and economic growth in countries at different levels of development, Research Policy, 41, 358-375.

King, N., \& Anderson, N. R. (2002). Managing innovation and change: a critical guide for organizations. Psychology at work. London, England: Thomson Learning.

Leonard, D., \& Sensiper, S. (1998). The role of tacit knowledge in group innovation. California Management Review, 40, $112-132$.

Lipsey, R. (2010). Measuring the location of production in a world of intangible productive assets, FDI, and intrafirm trade. Review of Income and Wealth, 56, 99-110.

Miron, E., Erez, M., \& Naveh, E. (2004). Do personal characteristics and cultural values that promote innovation, quality, and efficiency compete or complement each other? Journal of Organizational Behavior, 25, 175-199.

OECD (2014). Education at a Glance 2014. http://www.oecd.org/edu/European\%20Union EAG2014\%20Country\%20Note.pdf Accessed 11 January 2016.

Park, W. G. (2003). Do intellectual property rights stimulate R\&D and productivity growth? Evidence from cross-national and manufacturing industry data. In J. Putnam (Ed.), Intellectual Property Rights and Innovation in the KnowledgeBased Economy. Calgary: University of Calgary Press.

Park, W., \& Ginarte, J. C. (1997). Intellectual property rights and economic growth. Contemporary Economic Policy, 15(3), 51-61.

Romer, P. M. (1994). The origins of endogenous growth. Journal of Economic Perspectives, 8, 3-22.

Rossberger, R. J., \& Krause, D. E. (2015). Participative and team-oriented leadership styles, countries' education level, and national innovation: the mediating role of economic factors and national cultural practices. Cross-Cultural Research, 49(1), 20-56.

Sawa, T. (2016). Boosting Japanese innovation. The Japan Times, http://www.japantimes.co.jp/opinion/2016/11/21/ commentary/japan-commentary/boosting-japanese-innovation/\#.WF3e3Bsrl2w Accessed December 20, 2016

Schumpeter, J. (1934). The theory of economic development. Boston, MA: Harvard University Press.

Shin, S. J., \& Zhou, J. (2007). When is educational specialization heterogeneity related to creativity in research and development teams? Transformational leadership as a moderator. The Journal of Applied Psychology, 92, 1709-1721.

Smith, M., Busi, M., Ball, P., \& Van der Meer, R. (2008). Factors influencing and organisations ability to manage innovation: a structured literature review and conceptual model. International Journal of Innovation Management, $12,655-676$.

Wang, E. (2010). Determinants of R\&D investment: the extreme-bounds analysis approach applied to 26 OECD countries. Research Policy, 39(1), 103-116.

Weckowska, D. M., Molas-Gallart, J., Tang, P., Twigg, D., Castro-Martínez, E., Kijeńska-Dąbrowska, l., Libaers, D., Debackere, K. and Meyer, M. (2015). University patenting and technology commercialization-legal frameworks and the importance of local practice. R\&D Manage. doi:10.1111/radm.12123.

Zachariadis, M. (2003). R\&D, innovation, and technological progress: a test of the Schumpeterian framework without scale effects. Canadian Journal of Economics, 36(3), 566-686.

\section{Submit your manuscript to a SpringerOpen ${ }^{\circ}$ journal and benefit from:}

- Convenient online submission

Rigorous peer review

- Immediate publication on acceptance

- Open access: articles freely available online

- High visibility within the field

- Retaining the copyright to your article 